\title{
PEMBERDAYAAN WANITA MELALUI USAHA KRUPUK LELE ORGANIK DI DESA SUMBERNGEPOH, LAWANG KABUPATEN MALANG
}

\author{
Suhartatik $^{1)}$, Titik Purwati ${ }^{2)}$, Wilyati Agustina ${ }^{3)}$ \\ IKIP Budi Utomo \\ ${ }^{1)}$ tatik_sihhanto@yahoo.com ${ }^{2}$ titikpurwati62@gmail.com, ${ }^{3)}$ wilyanti_b@yahoo.com
}

\begin{abstract}
Women's empowerment is the focus of this community service activity in partnership with mothers from the Krupuk Business Group, Ibu Mujiati and Ibu Tuni. The purpose of this activity is to solve the problems faced by the organic catfish cracker business group partners in Sumberngepoh Village, Lawang, Malang Regency, in terms of production and management aspects. The targets to be achieved from this activity are training and additional production equipment for partners as an effort to empower the community.

Method of program implementation This activity goes through three stages, namely the planning stage, the implementation stage and the evaluation stage. The results achieved from this activity are: 1) a solution to production problems by adding/procuring new production equipment and raw materials for making organic catfish crackers; 2) the existence of solutions to management problems by holding management training which includes production, marketing, sanitation and hygiene. The final result shows that there are indicators of success with increased knowledge of partners and productivity of organic catfish crackers that increase with management training.
\end{abstract}

Keywords: Pemberdayaan wanita, krupuk lele organik, pelatihan manajemen

\section{ANALISIS SITUASI}

Mengacu pada Pujono dalam Purnamasari (2020) yang menyatakan bahwa pemberdayaan wanita berarti memberikan kekuatan dan kemampuan terhadap potensi yang dimiliki kaum wanita agar dapat diaktualisasikan secara optimal dalam prosesnya dan menempatkan wanita sebagai manusia seutuhnya. Hal inilah yang melandasi diadakannya kegiatan Program Kemitraan Masyarakat (PKM) bagi para ibuibu rumah tangga di lingkungan RW II Dukuh Krajan Desa Sumberngepoh Kec. Lawang, Kab. Malang untuk ikut ambil bagian dalam menopang ekonomi keluarga dengan usaha membuat Krupuk Lele Organik.

Salah satu kekuatan ("strengthen") yang mendukung kegiatan ini adalah sumberdaya alam Desa Sumberngepoh Kec. Lawang, Kab. Malang sebagai daerah pertanian yang sangat subur dan banyaknya sumber mata air. Sehingga hasil tanaman sayuran melimpah dan limbah dari sisa limbah sampah keluarga dapat dipergunakan untuk bahan makanan ikan lele yag dikenal dengan Lele Organik (tanpa menggunakan pelet).

Didukun oleh Adriani (2020) yang menyatakan bahwa pengelolaan limbah sampah rumah tangga adalah dimanfaatkan menjadi sumber bahan pakan ikan. Hal ini sejalan dengan penggunaan pakan lele organik sebagai bahan baku usaha krupuk lele organik di Desa Sumberngepoh, Kec. Lawang Kabupaten Malang.

Studi analisis diawali dengan kegiatan observasi dan survey langsung di lapangan, dimana kegiatan PKM ini bermitra dengan Kelompok Usaha Krupuk Lele Organik dan Kelompok Tani Sumber Makmur I yang berlokasi di Desa Sumberngepoh, Kec. Lawang Kabupaten Malang. Lokasi nya cukup mudah diakses dari Kota Malang kirakira 19 KM menuju Pasar Lawang Kabupaten Malang. Dan sekitar 3 KM menuju lokasi Dukuh Krajan Desa Sumberngepoh.

Berawal dari usaha Kelompok Tani yang dibina oleh Bapak Suroto pada tahun 
2005, kelompok usaha krupuk yang beranggotakan ibu-ibu anggota PKK di RW II Dukuh Krajan Desa Sumberngepoh Lawang mulai berkembang.

Mitra Kegiatan ke 1 adalah Kelompok Usaha krupuk yang diketuai oleh Ibu Mujiati, yang awalnya mengelola usaha krupuk puli bahan beras bersama anggotanya mampu memproduksi krupuk puli kurang lebih 50-60 $\mathrm{kg} /$ minggu.

Mitra Kegiatan ke 2 adalah Kelompok Usaha krupuk yang diketuai oleh Ibu Tuni, yang juga memproduksi krupuk miler bahan singkong. Kelompok usaha Ibu Tuni ini sebenarnya sudah berproduksi lebih lama dari kelompok yang lain, hanya kendala modal dan tenaga kerja.

Mitra Kegiatan ke 3 adalah Kelompok Tani Sumber Makmur I yang diketuai oleh bapak Suroto, sebagai pelopor dalam membina dan memotivasi kegiatan kelompok usaha krupuk. Dalam kegiatan ini Kelompok Tani Sumber Makmur I bertindak sebagai pemasok bahan baku lele organik yang sudah dikelola dan dibudidayakan oleh anggota Kelompok Tani Sumber Makmur I di kolam-kolam lele yang ada di Desa Sumberngepoh Lawang.

Status sosial dari kedua kelompok usaha krupuk ini adalah kelompok usaha mandiri yang dikelola oleh keluarga secara turun temurun. Sedangkan mitra usaha lain sebagai pemasok lele organik tergabung dalam Kelompok Tani Sumber Makmur I, Desa Sumberngepoh Lawang, Kabupaten Malang.

Mengacu pada hasil survei yang telah dilaksanakan dalam kegiatan ini, permasalahan yang dihadapi oleh kelompok usaha krupuk di Desa Sumberngepoh Lawang, Kabupaten Malang ini adalah sebagai berikut :

1. Permasalahan Produksi antara lain:

a. Terbatasnya jenis alat produksi pembuatan krupuk.

b. Terbatasnya bahan baku pembuatan krupuk c. Terbatasnya jenis atau macam krupuk yang sudah diproduksi

d. Terbatasnya daerah pemasaran hasil produksi krupuk

2. Permasalahan Manajemen antara lain :

a. Belum dilaksanakannya manajemen yang tepat yang dapat meningkatkan produktivitas hasil krupuk.

b. Daya saing kelompok usaha krupuk lainnya/kompetitor.

c. Kelangsungan dukungan modal usaha.

Target capaian yang diharapkan dari kegiatan ini adalah adanya solusi dari permasalahan baik produksi maupun manajemen meliputi: (1) adannya penambahan dan pengadaan alat produksi pembuatan krupuk lele organik, (2) adanya penambahan pengadaan bahan baku pembuatan krupuk lele organik, (3) adanya solusi dari permasalahan manajemen produksi, pemasaran, sanitasi dan kebersihan dengan memberikan pelatihan manajemen sederhana sesuai kebutuhan para mitra sehingga sesuai dengan target yang diharapkan.

\section{METODE PELAKSANAAN}

Metode pelaksanaan program Kegiatan ini melaui tiga tahapan yaitu tahap perencanaan, tahap pelaksanaan dan tahap evaluasi. Tahap perencanaan dimulai dengan kegiatan observasi dan sosialisasi di lapangan, tahap pelaksanaan adalah dilaksanakannya kegiatan pelatihan manajemen bagi ibu-ibu kelompok usaha krupuk lele organik di Desa Sumberngepoh, Lawang Kabupaten Malang dan penyerahan penambahan alat produksi dan bahan baku pembuatan krupuk lele organik, sedangkan tahap evaluasi adalah kegiatan akhir yang dilaksanakan dengan pengamatan dari hasil pelatihan dan praktek langsung pembuatan krupuk lele organik, sehingga diharapkan ada dampak yang signifikan setelah diadakannya kegiatan ini yang dapat meningkatkan taraf hidup dan ekonomi keluarga. 


\section{HASIL DAN PEMBAHASAN}

Metode yang dipergunakan dalam kegiatan ini ada 3 tahapan yaitu :

1. Tahap Persiapan meliputi kegiatan observasi dan sosialisasi.

Kegiatan observasi dilaksanakan dengan terjun langsung ke tempat para mitra yaitu usaha krupuk Ibu Mujiati, Ibu Tuni dan Kelompok tani Sumber Makmur I Bapak Suroto. Kegiatan minggu I sampai minggu IV diawali dengan mengikuti kegiatan para mitra sebelum diadakannya kegiatan pelatihan.

Memotret secara factual bagaimana langkah-langkah Mitra I dan Mitra II Ibu Mujiati dan Ibu Tuni mulai mengolah krupuk lele organik dengan cara-cara tradisional yang sudah mereka kerjakan secara turun temurun. Misalnya bahan yang digunakan ikan lele, tepung dicampur dengan bahan tradisional "bleng", proses pembuatan krupuk menggunakan alat-alat produksi yang terbatas dan sederhana/manual misalnya alat penggorengan terbatas, mesin blender ikan terbatas, belum ada sealer pembungkus plastic, memasak masih menggunakan dapur tradisional dengan sumber kayu bakar dan sekam padi.

Sedangkan kondisi Mitra III Kelompok tani Sumber Makmur I sebagai pemasok ikan lele organik mengalami kesulitan karena tidak dapat memenuhi kebutuhan mitra karena terbatasnya jumlah lele yang dipanen. Kegiatan Sosialisasi diberikan kepada para mitra tentang diadakannya Kegiatan PKM yaitu kegiatan yang dapat memberikan solusi dari permasalahan yang dihadapi para mitra yaitu dengan memberikan Pelatihan Manajemen mencakup produksi, pemasaran, sanitasi dan kebersihan. Dan juga target penambahan/pengadaan alat produksi sehingga diharapkan dapat menaikan produktivitas para mitra.

2. Tahap Pelaksanaan yaitu fokus pada kegiatan pelatihan Manajemen, penambahan /pengadaan alat produksi dan bahan baku pembuatan krupuk lele organik.

Kegiatan pelatihan diberikan oleh para pakar sesuai dengan bidang keahliannya yang diadakan dalam tiga sesi yaitu Pelatihan Manajemen produksi menyangkut seluk beluk produksi dan teknologi tepat guna dalam mengolah bahan makanan. Sekaligus praktek langsung bagaimana mengolah krupuk lele organik bernilai jual tinggi. Dilanjutkan dengan topik pemasaran, sanitasi dan kebersihan yang mencakup bagaimana cara mencari peluang pemasaran, daerah dan sasaran target pemasaran, promosi serta seluk beluk kebersihan dalam mengolah bahan makanan termasuk penampilan segi packing.

Adapun rincian dari Pelatihan Manajemen adalah sebagai berikut:

a. Pelatihan Manajemen Produksi dilaksanakan ini diikuti oleh para mitra kelompok usaha krupuk Ibu Mujiati, Ibu Tuni dan kelompok tani Sumber Makmur I Bapak Suroto.

Kegiatan pelatihan Manajemen Produksi dilaksanakan dengan memberikan materi utama yaitu bagaimana memilih Teknologi tepat guna dalam mengembangkan produk-produk olahan bahan pertanian dan perikanan. Disamping memberikan materi pelatihan secara teoritis para mitra juga diberi kesempatan praktek langsung langkah langkah proses pembuatan Krupuk Lele Organik secara detail, sehingga para mitra paham dan mampu mempraktekan nya.

Tahap-tahap pengolahan Krupuk Lele Organik dipaparkan sebagai berikut

(1) Pemilihan Bahan untuk pembuatan Krupuk Lele Organik: $1 \mathrm{Kg}$ Daging Ikan Lele Organik 500 Gr Tepung Tapioka 
6 Siung Bawang Putih

1 Sendok makan Garam dapur

1 Sendok teh Gula pasir

1 Sendok teh Terasi

2 Butir Telur Bebek

(2) Langkah Pembuatan Krupuk Lele Organik :

a) Cuci bersih Ikan Lele Organik, kemudian diambil dagingnya.

b) Siapkan bawang putih yang sudah dihaluskan.

c) Masukan dalam blender semua bahan yaitu daging Ikan Lele Organik, bawang putih halus, garam, gula, terasi, telur bebek.

d) Campur semua bahan dengan tepung tapioka sedikit demi sedikit sampai semua bahan tercampur rata membentuk sebuah adonan.(Jika terlalu kental bisa ditambahkan air secukupnya)

e) Masukan adonan dalam plastic roll diameter 5-6 cm.

f) Kukus adonan yang sudah dimasukan ke dalam plastic selama +- 30 menit, setelah matang angkat dan dinginkan.

g) Keluarkan adonan yang sudah dingin siap diiris tipis-tipis, kmudian dijemur di terik matahari sampai benar-benar kering.

h) Jika sudah benar-benar kering, Krupuk Lele Organik siap dikemas dalam plastic dan siap digoreng/dipasarkan.

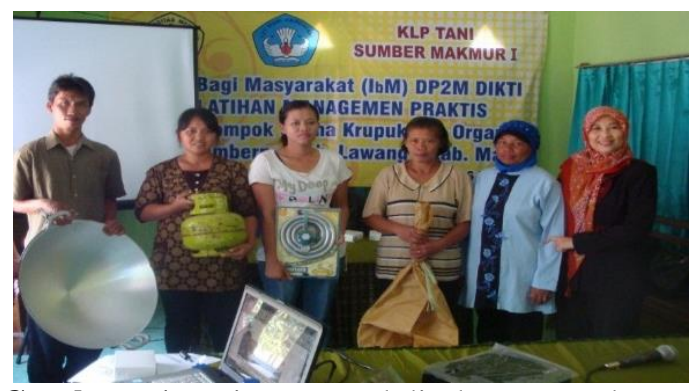

Gambar 1. Tim Pengabdi bersama dengan bapak/ibu pelaksana b. Pelatihan Manajemen Pemasaran dilaksanakan dan diikuti oleh para mitra kegiatan PKM. Materi yang diberikan dalam kegiatan pelatihan ini adalah seluk beluk manajemen dan strategi pemasaran, kendala dan solusi pemasaran yang dapat menambah wawasan dari para kelompok usaha yang tadinya belum begitu paham tentang aspek-aspek pemasaran, bagaimana promosi, bagaimana memperluas daerah pemasaran, dll.

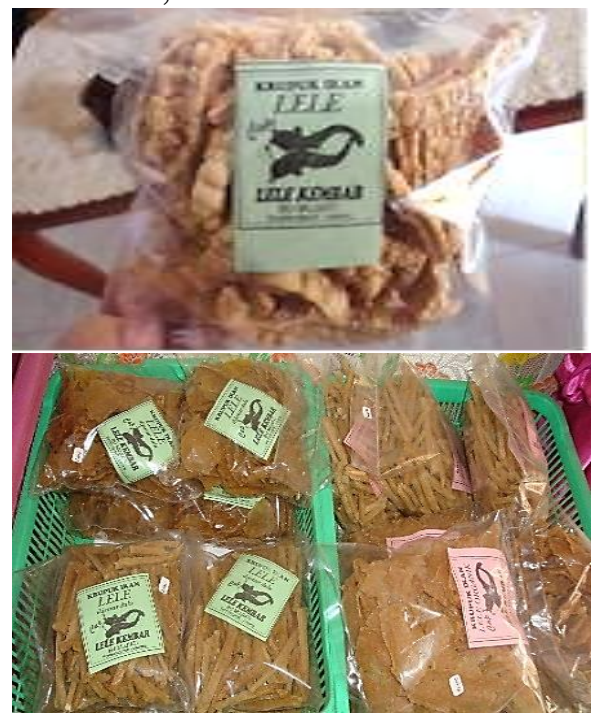

Gambar 2. Sampel Produk

c. Sosialisasi Sanitasi dan Kebersihan dilaksanakan dengan memberikan materi tentang seluk beluk Sanitasi dan Kebersihan dalam proses pembuatan krupuk lele organic dan juga memberikan contoh-contoh bentuk kemasan produk krupuk lele organic yang menarik, bernilai jual tinggi dan kekinian sesuai dengan perkembangan zaman. 


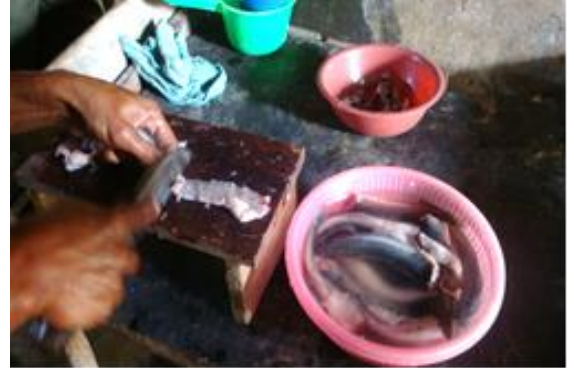

Gambar 3. Salah satu tahap produksi.

3. Tahap Evaluasi akhir dilaksanakan dengan pengamatan dari hasil sebelum dan sesudah diadakan pelatihan dan praktek langsung pembuatan krupuk lele organik, sehingga diharapkan ada dampak yang signifikan setelah diadakannya kegiatan yang dapat memberdayakan ekonomi keluarga.

Sesuai target awal dari kegiatan PKM ini yang bertujuan untuk memberikan solusi dari permasalah-permasalahan yang dihadapi oleh para mitra, yaitu kelompok usaha krupuk lele organik di Desa Sumberngepoh Lawang, Kabupaten, Malang, maka evaluasi target capaian dengan adanya program ini sangatlah jelas yaitu : 1) sudah dapat menjawab permasalahan produksi dengan adanya penambahan maupun pengadaan alat produksi dan bahan baku pembuatan krupuk lele organik; 2) dari segi manajemen dengan mengadakan pelatihan manejemen yang dapat meningkatkan produktivitas hasil krupuk, termasuk produksi, pemasaran, sanitasi dan kebersihan. Terbukti dengan antusiasnya para mitra dalam mengikuti kegiatan ini.

\section{KESIMPULAN}

Menilik dari evaluasi dari permasalahan mitra serta respon positif dari mitra dan masyarakat setempat menunjukkan indikator keberhasilan dengan adanya program PKM ini antara lain :

a. Terlaksananya penambahan/pengadaan alat produksi pembuatan krupuk lele organik sehingga dapat meningkatkan produksi dari krupuk lele organik. b. Terlaksananya kegiatan pelatihan manajemen bagi kelompok usaha krupuk lele organik sehingga memotivasi para mitra untuk memahami dan melaksanakan manajemen sesuai dengan kemampuan dan kebutuhan para mitra mencakup produksi, pemasaran, sanitasi dan kebersihan.

c. Adanya variasi jenis dan bentuk krupuk lele organik yang mempunyai cita rasa tersendiri yang berbeda di daerah Sumberngepoh, Lawang.

d. Adanya motivasi dan kesadaran dari para mitra kelompok usaha krupuk lele organik untuk membuat produk krupuk yang sehat dan hygienis sesuai dengan standart pemerintah yaitu tanpa menggunakan bahan-bahan kimia (mis. Bleng) tetapi diganti dengan bahan baku lele organik.

Para mitra kelompok usaha krupuk lele organik dan kelompok tani Sumber Makmur sangat berperan aktif dalam mendukung kegiatan ini, dilihat dari antusias kelompok untuk selalu membuat uji coba pembuatan krupuk lele organik berulang-ulang dan uji coba tester ke berbagai kalangan yang dapat memberikan saran dan masukan tentang hasil produk krupuk ikan lele organik yang sudah dibuat. Dan bahkan dicoba dipasarkan secara internal dalam bazar2 dan warung-warung di daerah Sumberngepoh Lawang dan Malang.

Bagi para mitra manfaat yang didapat dari aspek produksi yaitu : dengan diterimanya penambahan/pengadaan alat produksi pembuatan krupuk lele organik yaitu berupa seperangkat kompor gas dan perlengkapannya, serta penambahan bahan baku pembuatan krupuk lele organik dan ditambah pula bantuan 2500 ekor bibit lele organik kepada kelompok tani Sumber Makmur sebagai pemasok lele organik. Bantuan ini sangat bermanfaat untuk menunjang keberlangsungan produk krupuk lele organik.

Tidak hanya manfaat dari aspek produksi tetapi juga manfaat dari aspek 
manajemen yaitu : para mitra dapat menerima ilmu yang tadinya belum mereka dapatkan serta bagaimana memahami dan melaksanakan manajemen sederhana yang sesuai dengan kebutuhan mereka. Ditambah pula pengetahuan bagaimana menghasilkan produk yang sehat dan hygienis tanpa menggunakan bahan kimia, tetapi dapat diganti dengan menggunakan bahan-bahan tradisional yang mudah didapat, misalnya dalam pembuatan krupuk tidak lagi memakai garam bleng tetapi bisa diganti dengan menggunakan telur bebek.

\section{DAFTAR PUSTAKA}

Handoyo, Joko. 2012. Klaten Bersinar:Produksi Krupuk di Kabupaten Klaten. Klaten, Universitas Widya Dharma.

Trans.TV. 2012. Reportase Investigasi: Produk Krupuk Berbahaya. Jakarta.

Yuli Andriani, Irfan Zidni, dan Muhamad Fatah Wiyatna 2020. Modifikasi Mesin Pressing Limbah Rumah Tangga untuk Pembuatan Pakan Ikan di Desa Tanjungsari, Sumedang, Jawa Barat Universitas Padjadjaran Bandung. Jurnal Media Kontak Tani Ternak, Mei 2020, 2(2):1-7.

http://jurnal.inpad.ac.id/mktt/index download tanggal 11 Desember 2020

Vidya Purnamasari, Vika Annisa Qurrata, *Bagus Shandy Narmaditya. 2020. Pemberdayaan Wanita Melalui Peluang Usaha dalam Peningkatan Ekonomi Lokal. Malang, Universitas Negeri Malang. Jurnal Graha PengabdianVol.2, No.1 (2020). http://journal2.um.ac.id/index.php/j gp download tanggal 12 Desember 2020 